\title{
EL ESTATUTO CONSTITUCIONAL DEL NO NACIDO: EVOLUCIÓN Y SITUACIÓN ACTUAL EN ESPAÑA
}

ÁNGEL J. GÓMEZ MONTORO 
SUMARIO

1. LA LEGALIZACIÓN DEL ABORTO EN ESPAÑA Y LA STC 53/1985: A) DE LA TIPIFICACIÓN PENAL A LA DESPENALIZACIÓN EN DETERMINADOS SUPUESTOS; B) LA STC 53/1985: I) DERECHO A LA VIDA Y VIDA EN FORMACIÓN; II) LA VIDA DEL NO NACIDO COMO BIEN CONSTITUCIONAL; III) LA CONSTITUCIONALIDAD DE LOS SUPUESTOS DE DESPENALIZACIÓN PREVISTOS EN LA LEY; IV) LAS CONDICIONES PARA LA CONSTITUCIONALIDAD DE LA DESPENALIZACIÓN; C) LA NUEVA LEY ORGÁNICA Y SU NO IMPUGNACIÓN. 2. DEL SISTEMA DE INDICACIONES AL SISTEMA DE PLAZOS: LA LEY ORGÁNICA 2/2010, DE 3 DE MARZO, DE SALUD SEXUAL Y REPRODUCTIVA Y DE LA INTERRUPCIÓN VOLUNTARIA DEL EMBARAZO: A) LA EVOLUCIÓN DEL ABORTO EN ESPAÑA BAJO LA LEY DE 1985; B) LOS ARGUMENTOS PARA LA REFORMA Y EL CONTEXTO DE LA NUEVA REGULACIÓN; C) LA NUEVA REGULACIÓN. 3. UN DEBATE ABIERTO: A) LAS DUDAS SOBRE LA CONSTITUCIONALIDAD DE LA LEY; B) LA FALLIDA REFORMA DE LA LEY. 4. LA DESPROTECCIÓN DEL EMBRIÓN EN LAS LEYES SOBRE FECUNDACIÓN IN VITRO Y SOBRE EL USO DE TEJIDOS Y ÓRGANOS EMBRIONARIOS Y LAS SSTC 212/1996 Y 116/1999: A) LAS LEYES 35/1988, SOBRE TÉCNICAS DE REPRODUCCIÓN ASISTIDA Y 42/1988, DE DONACIÓN Y UTILIZACIÓN DE EMBRIONES Y FETOS HUMANOS O DE SUS CÉLULAS, TEJIDOS U ÓRGANOS; B) NEGACIÓN DEL DERECHO A LA VIDA DEL EMBRIÓN Y CONSECUENCIAS DE SU CONSIDERACIÓN COMO BIEN JURÍDICO CONSTITUCIONALMENTE PROTEGIDO: I) EL EMBRIÓN NO ES TITULAR DEL DERECHO A LA VIDA; II) DOS NUEVAS CATEGORÍAS —PREEMBRIONES Y EMBRIONES NO VIABLES - Y SU RELEVANCIA JURÍDICA; III) LOS EMBRIONES SOBRANTES; IV) LA AUSENCIA DE TUTELA PENAL; V) UN CONCEPTO DÉBIL DE DIGNIDAD. 5. LA EVOLUCIÓN LEGISLATIVA. 6. UN MODELO DE (DES) PROTECCIÓN GRADUALISTA DE LA VIDA EN FORMACIÓN 


\title{
EL ESTATUTO CONSTITUCIONAL DEL NO NACIDO: EVOLUCIÓN Y SITUACIÓN ACTUAL EN ESPAÑA ${ }^{1}$
}

\author{
ÁNGEL J. GÓMEZ MONTORO² \\ Catedrático de Derecho Constitucional \\ Universidad de Navarra
}

\section{LA LEGALIZACIÓN DEL ABORTO EN ESPAÑA Y LA STC 53/1985}

\section{a) De la tipificación penal a la despenalización en determinados supuestos}

En el momento en que entró en vigor la Constitución de 1978 el aborto era en España, como en tantos otros países, un delito ${ }^{3}$. El nuevo texto constitucional incluyó un completo catálogo de derechos entre los que ocupa un lugar preeminente el derecho a la vida (art. $15 \mathrm{CE}$ ), sin que contenga ningún pronunciamiento expreso sobre el estatus del nasciturus. No obstante, ya durante los debates de la Constitución estuvo presente la cuestión del aborto al discutirse cuál debía ser la expresión para designar los sujetos del derecho a la vida ${ }^{4}$. El Anteproyecto de Constitución establecía que «todos tienen derecho a la vida y a la integridad física»; sin embargo, como consecuencia de una enmienda, la redacción fue sustituida por «el derecho de la persona a la vida y a la integridad física y moral son inviolables». A ese texto se presentó una nueva enmienda en la que se proponía la vuelta a la redacción inicial y ello

${ }^{1}$ El presente trabajo, en su versión inglesa, se incluirá en un volumen editado por P. Zambrano y W. Saunders sobre la situación legal y los leading cases sobre la vida humana en formación en diversos países del mundo, que publicará la editorial Peter Lang. Ese destino explica algunas afirmaciones y comentarios de contexto que pueden tener menos sentido para el lector español. Agradezco a los editores la autorización para su publicación en esta Revista.

2 Ángel J. Gómez Montoro. Catedrático de Derecho Constitucional. Universidad de Navarra. Facultad de Derecho. Campus Universitario. 31009 Pamplona. Navarra (España). Email: gmontoro@unav.es

${ }^{3}$ Los arts. 411 a 417 del Código Penal de 1944 entonces vigente castigaban todo aborto provocado con penas tanto para el que lo provocara como para la mujer que consentía el aborto (aunque las penas para esta última eran sensiblemente menores).

${ }^{4}$ La evolución del texto del artículo 15, incluidos los debates que suscitó en las Cámaras, puede encontrarse en http://www.congreso.es/est_consti/. 
por las dudas que el término persona podía suscitar y, más en concreto, por el hecho de que, según el art. 29 del Código Civil, la personalidad está vinculada al nacimiento. La enmienda fue aceptada por un estrecho margen pero en los debates quedó clara una falta de acuerdo entre las fuerzas políticas sobre la constitucionalidad o no del aborto, que necesariamente se debería plantear más adelante ${ }^{5}$.

La aprobación de la Constitución no cambió, en todo caso, el régimen del aborto que siguió siendo básicamente un delito, aunque en los primeros años del nuevo texto constitucional la cuestión estuvo presente tanto en los debates sobre la reforma del Código Penal como en algunas decisiones del Tribunal Constitucional que abordaron el tema colateralmente. Por lo que se refiere al primer punto, en septiembre de 1979 el Consejo de Ministros aprobó un proyecto de ley que, si bien mantenía el delito de aborto en los mismos términos, reducía considerablemente sus penas; pero el proyecto no llegó a aprobarse ${ }^{6}$. En 1981 se presentó por parte del Grupo Parlamentario Comunista una proposición de ley de despenalización que tampoco prosperó ${ }^{7}$.

En cuanto a las decisiones del Tribunal Constitucional deben tenerse en cuenta las SSTC 75/1984 y 70/1985, ambas recaídas en procesos de amparo. En el primer caso, se recurría una condena impuesta a una ciudadana española, que había abortado en Inglaterra, y a su cómplice. En realidad, la cuestión planteada no tenía directamente que ver con la constitucionalidad o no del delito de aborto sino con la construcción que hicieron los tribunales para condenar a los recurrentes y que el Tribunal Constitucional consideró implicaba una extensión analógica contraria al principio de legalidad penal del art. 25.1 CE, lo que le llevó a otorgar el amparo. Interesa, no obstante, destacar dos aspectos de esta sentencia: el primero, la afirmación del Tribunal de que, de acuerdo con el art. $15 \mathrm{CE}$, «la vida humana en formación es un bien que constitucionalmente merece protección» (FJ 6. ${ }^{\circ}$ ), un argumento que será esencial en la posterior STC 53/1985, que optó por examinar la protección del embrión desde la perspectiva de un bien constitucional y no desde la existencia de un derecho subjetivo a la vida. El segundo, el voto particular concurrente del Magistrado Tomás y Valiente, mucho más radical: en su opinión, una interpretación sistemática de la Constitución evidencia que «la persona humana es titular de los derechos fundamentales contenidos en el artículo 15 de la CE. El feto y, antes, el embrión no son persona humana, sino mera spes hominis». Para este Magistrado, puesto que según el art. 29

\footnotetext{
5 Sobre el debate parlamentario y el alcance de las distintas posturas puede verse G. Rodríguez Mourullo, «Comentario al art. 15 de la Constitución», en O. Alzaga (dir.), Comentarios a la Constitución Española de 1978, Tomo II, Edersa, Madrid 1997, págs. 270 y sigs.

${ }^{6}$ El proyecto se publicó en el Boletín Oficial de las Cortes Generales, Congreso de los Diputados, el 17 de enero de 1980. En la redacción original elaborada por un grupo de expertos en el seno de la Comisión General de Codificación, se había incluido la despenalización del aborto en los supuestos de riesgo para la vida y salud de la madre, violación y malformaciones en el feto, pero la propuesta no fue asumida por el Gobierno (vid. J. Cerezo Mir, «La regulación del aborto en el proyecto de nuevo Código penal español», Anuario de Derecho Penal y Ciencias Penales, 1982, tomo 35, págs. 564 y sigs.).

7 Proposición de ley de regulación de la interrupción voluntaria del embarazo, en Boletín Oficial de las Cortes Generales. Congreso de los Diputados, 14 de julio de 1981, págs. 529-535.
} 
del Código Civil el nacimiento determina la personalidad, «quien no es persona no puede ser, no es, titular de derechos».

En parecidos términos pero aún más categóricos se pronunció meses más tarde el mismo Tomás y Valiente en el voto particular a la STC 70/1985, dictada por tanto, después de la STC 53/1985 que examinó la constitucionalidad de la ley que despenalizaba el aborto pero antes de que ésta entrara en vigor: para el Magistrado disidente, el sistema punitivo del delito de aborto previsto en el Código Penal es contrario a la Constitución "porque no tiene en cuenta la existencia de aquellos derechos de la mujer embarazada derivados de los artículos 15 y $10 \mathrm{CE}(. .$.$) , derechos que entran en$ conflicto con el bien que es el nasciturus, en cuanto vida humana en formación y que, en determinadas hipótesis, deben prevalecer» ${ }^{8}$.

En 1982, unos años antes de que las mencionadas sentencias fueran dictadas, accedió al Gobierno el Partido Socialista Obrero Español que llevaba en su programa la promesa de despenalizar el aborto. Y en el mes de febrero de 1983 envió a las Cortes para su tramitación un proyecto de ley de reforma de Código Penal que fue aprobado y en el que, si bien el aborto seguía siendo fundamentalmente un delito, se establecían una serie de supuestos en los que no sería punible; estos eran: 1. «Grave peligro para la vida o la salud de la embarazada»; 2. Embarazo debido a una violación; 3. Y «que sea probable que el feto habrá de nacer con graves taras físicas o psíquicas».

Contra la nueva ley, y antes de su promulgación y publicación, se interpuso un recurso previo de inconstitucionalidad, que llevaba consigo la suspensión de la tramitación hasta el pronunciamiento del Tribunal Constitucional ${ }^{9}$. Este se materializó en su STC 53/1985, de 11 de abril.

\section{b) LaSTC 53/1985}

Como era de prever, la impugnación originó un intenso debate tanto en la doctrina - y en la sociedad en general_ como en el seno mismo del Tribunal Constitucional, hasta el punto de que este se partió en dos bloques de seis Magistrados, a favor y en contra de la constitucionalidad de la ley, siendo finalmente decisivo el voto de calidad del Presidente ex art. 90.1 LOTC. La sentencia vino a aceptar la constitucionalidad del sistema de indicaciones y, en concreto, la de los tres supuestos previstos en la ley si bien declaró, con una argumentación que sería objeto de duras críticas en los votos particulares, la inconstitucionalidad de la ley por no establecer garantías

\footnotetext{
8 Se trataba, sin embargo, de una postura minoritaria y nunca se llegó a cuestionar ante el Tribunal Constitucional la regulación del aborto previa a su despenalización.

9 Este recurso previo, no previsto en la Constitución pero introducido en la Ley Orgánica del Tribunal Constitucional para los Estatutos de Autonomía y las demás leyes orgánicas, fue especialmente polémico y, de hecho, fue suprimido en 1985. En 2015 fue reintroducido pero solo para los Estatutos de Autonomía (Ley Orgánica 12/2015). Vid. A.J. Gómez Montoro, «El control previo de constitucionalidad de Estatutos de Autonomía y demás leyes orgánicas», Revista Española de Derecho Constitucional, núm. 22, 1988, págs. 123-174.
} 
suficientes para asegurar que el aborto solo se produce en los supuestos legalmente previstos y evitar posibles fraudes.

i) Derecho a la vida y vida en formación

El punto de partida de la sentencia es la consideración de que el derecho a la vida garantizado por el art. 15 de la Constitución es «la proyección de un valor superior del ordenamiento jurídico constitucional — la vida humana-y constituye el derecho fundamental esencial y troncal en cuanto es el supuesto ontológico sin el que los restantes derechos no tendría existencia posible». Un derecho, además, indisolublemente unido con «el valor jurídico fundamental de la dignidad de la persona, reconocido en el art. 10» (FJ 3).

Por lo que a la vida en formación se refiere, el Tribunal realiza importantes afirmaciones en el fundamento jurídico 5. Sostiene, en concreto, que «la vida humana es un devenir, un proceso que comienza con la gestación (...), y que termina con la muerte», así como que la gestación genera «un tertium existencialmente distinto de la madre». Siendo la vida un proceso, existen cambios cualitativos que son relevantes para el Derecho, en especial el nacimiento y, previamente, «el momento a partir del cual el nasciturus es ya susceptible de vida independiente de la madre».

Como consecuencia de las anteriores afirmaciones entiende el Tribunal que si la Constitución protege la vida, «no puede desprotegerla en aquella etapa de su proceso que no solo es condición para la vida independiente del claustro materno, sino que es también un momento del desarrollo de la vida misma» (FJ 5).

ii) La vida del no nacido como bien constitucional

Admitida la obligación constitucional de proteger la vida del nasciturus se plantea cuál es su alcance y, más específicamente, si esa protección deriva de la titularidad de un derecho subjetivo o más bien de su consideración como un bien constitucionalmente protegido. Se ha convertido en lugar común la afirmación de que esta alternativa es resuelta por el Tribunal rechazando que el no nacido sea titular del derecho a la vida del art. $15 \mathrm{CE}$; así lo reitera parte de la doctrina y lo ha sostenido el propio Tribunal en sentencias posteriores ${ }^{10}$. Sin embargo, una detenida lectura del razonamiento del Tribunal revela que en ella no se contiene tanto una fundamentación del porqué de la no titularidad (que ni siquiera se afirma de modo categórico) cuanto un análisis y posterior rechazo de los argumentos expuestos por los recurrentes. Estos habían alegado la existencia de un derecho subjetivo del nasciturus que se deduciría

${ }^{10}$ En las SSTC 212/1996 y 116/1999, que analizaremos más adelante, reitera el Tribunal que «el art. $15 \mathrm{CE}$, en efecto reconoce como derecho fundamental el derecho de todos a la vida, derecho fundamental del que, como tal y con arreglo a la STC 53/1985, son titulares los nacidos, sin que quepa extender esta titularidad a los nascituri» (FFJJ 3 y 4 respectivamente). 
de la interpretación que debe darse al termino «todos» del art. 15 CE a la luz tanto de los debates parlamentarios como de una interpretación sistemática de la Constitución y de los tratados internacionales de derechos ratificados por España. El Tribunal rechaza el primero de los argumentos porque, si bien la introducción del término «todos» sustituyendo al de «persona» perseguía, como ya se ha visto, proteger al nasciturus, ese término tiene una ambigüedad que no se despejó en los debates; de estos se deduciría la necesidad de protección pero no la titularidad del derecho (FJ 5).

A la misma conclusión se llegaría desde una interpretación sistemática de la Constitución pues el término «todos» que se utiliza en otros preceptos constitucionales relativos a derechos (art. 9.2, 17.4, 18.1 y 4, 20.3, 27 ..) hace referencia claramente a los nacidos. Por último, tampoco sería concluyente el argumento relativo a los tratados internacionales pues tanto la versión francesa como la española del art. 6 del Pacto Internacional de Derecho Civiles y Políticos y del art. 2 del Convenio Europeo de Derechos Humanos usan el término persona, sin que el TEDH se hubiera pronunciado entonces sobre su alcance (FJ 7).

Por las razones expuestas, concluye el Tribunal que «los argumentos aducidos por los recurrentes no pueden estimarse para fundamentar la tesis de que el nasciturus le corresponde también la titularidad del derecho a la vida». A partir de aquí, la sentencia no entra a analizar si existen o no otras razones que justifican la titularidad del derecho $y$, de cualquier forma, no llega a negarla expresamente sino que afirma que «en todo caso, y ello es lo decisivo para la cuestión objeto del presente recurso, debemos afirmar que la vida del nasciturus (...) es un bien jurídico constitucionalmente protegido por el art. 15 de nuestra norma fundamental» (FJ 7). Una protección que incluye dos obligaciones del Estado: la de abstenerse de interrumpir o de obstaculizar el proceso de la gestación y la de establecer un sistema legal de defensa de la vida que implique una protección efectiva de la misma, y que incluya también la garantía penal ${ }^{11}$.

11 No hay, sin embargo, en la argumentación del Tribunal ninguna referencia a si el nasciturus es o no persona. Quizás para evitar confusión con el concepto de persona a efectos civiles que, como antes se ha dicho, se vinculaba en nuestra tradición con el nacimiento, o quizás porque admitirlo debería llevar a la ilicitud del aborto. «En la medida en la que está permitido abortar (...) — afirma categóricamente G. Jakobs - «el feto no puede ser considerado como una persona» [«¿Existe un aborto lícito de personas?», Poder Judicial, núm. 60, 2000 (IV), pág. 168]. Y J.M. Silva, partiendo precisamente de la distinción de Jakobs entre «Derecho penal de ciudadanos» y «Derecho penal de enemigos» ha denunciado el tratamiento del aún no nacido como no-persona, degradándolo al Derecho de cosas o, en el mejor de los casos, a una condición de persona de segunda clase ( «Los indeseados como enemigos. La exclusión de seres humanos del status personae», Revista Electrónica de Ciencia Penal y Criminología, 09-01, 2007, págs. 1-18). Por eso algunos autores han insistido en la necesidad de un concepto constitucionalmente adecuado de persona: vid. en este sentido los trabajos de A. Ollero, «Todos tienen derecho a la vida. ¿Hacia un concepto constitucional de persona?, recogido en el volumen Bioderecho. Entre la vida y la muerte, Thomson-Aranzadi, Cizur Menor 2006, págs. 75 y sigs.; en especial 100 y sigs.; de A.L. Martínez-Pujalte, «Hacia un concepto constitucional de persona», Cuadernos Constitucionales de la Cátedra Fadrique Furió Ceriol, núms. 11-12, 1995, págs. 135-155 y de P. Sánchez-Ostiz, « ¿Tienen todos derecho a la vida? Bases para un concepto constitucional de persona», Revista Electrónica de Ciencia Política y Criminología, 11-11, 2009. 
Hay en el razonamiento del Tribunal un salto lógico de consecuencias relevantes ${ }^{12}$ pues «lo decisivo» no es solo determinar si hay una obligación de proteger sino también precisar el fundamento de esa protección ya que no es lo mismo ostentar la titularidad de un derecho fundamental que ser un «bien» constitucionalmente protegi$\mathrm{do}^{13}$. Y a lo largo de todos estos años, el Tribunal no ha expuesto más razones que las utilizadas para refutar los argumentos de los recurrentes, algo que no parece suficiente pues, por su posición y función de supremo intérprete de la Constitución, no está vinculado a los argumentos de las partes a la hora de determinar quién es titular de derechos o cuáles son sus contenidos constitucionalmente protegidos.

Y entiendo que la conclusión de que el nasciturus no es titular del derecho a la vida no se impone por sí misma, pues si bien es cierto que, como recuerda también la sentencia, el nasciturus se encuentra en una especialísima relación de dependencia respecto de la madre, tampoco puede ignorarse que lo tutelado por el art. $15 \mathrm{CE}$ no es la vida en abstracto sino el «derecho a la vida» de todo - y cada concreto- ser humano y, como se ha visto, el Tribunal afirma de manera categórica que la vida humana comienza con la gestación y que con ella se genera «un tertium existencialmente distinto de la madre» (STC 53/1985, fundamento jurídico 5), es decir, un nuevo ser humano ${ }^{14}$.

12 De «salto argumental cuanto menos discutible» habla C. Vidal («El estatuto jurídico del embrión en la Jurisprudencia del Tribunal Constitucional Español», Estudios de Deusto, vol. 60, núm. 1, pág. 384). M.A. Alegre Martínez, por su parte, califica la decisión de negar la titularidad del derecho al nasciturus de «incoherente e inexplicable» («Apuntes sobre el derecho a la vida en España. Constitución, jurisprudencia y realidad», Revista de Estudios Políticos, núm. 53, 2002, pág. 347).

13 Como sostiene J.M. Silva Sánchez, «no existe estado de necesidad alguno que pueda justificar privar a otro de su vida, a la que tiene derecho. Por tanto, la admisión del aborto como un acto lícito ha de partir de la negación del derecho a la vida del concebido» («Los indeseados como enemigos. La exclusión de seres humanos del status personae», cit., pág. 7). Aunque hay quien sostiene lo contrario (y el propio Tribunal Constitucional alemán ha admitido la constitucionalidad del aborto a pesar de reconocer que el feto es titular del derecho a la vida), la mayoría de los autores, incluidos quienes defienden la constitucionalidad del aborto, consideran que la existencia de un derecho subjetivo haría ilícito el aborto. Son significativas, por ejemplo, las palabras del Magistrado Tomás y Valiente en su voto particular a la STC 53/1985: «comprendo, aun sin compartirla, la oposición a la no punición del aborto en defensa de un supuesto derecho fundamental del nasciturus a la vida. Es una línea clásica de razonamiento desde la que se podría llegar, con innegable coherencia interna, a un fallo de inconstitucionalidad en determinadas regulaciones de despenalización o legalización del aborto». Véase en un sentido similar C. Tomás-Valiente, «La jurisprudencia constitucional española sobre el aborto», en Ian Shapiro, Pablo de Lora Deltoro y Carmen Tomás-Valiente, La Suprema Corte de Estados Unidos y el aborto, Fundación Coloquio Jurídico Europeo, Madrid 2009, págs. 102-103.

14 Un análisis crítico de esta separación entre protección del feto y sujeto de derecho en A. Ollero, «Todos tienen derecho a la vida. ¿Hacia un concepto constitucional de persona?, cit., págs. 81 y sigs. Critica este autor «el intento de refugiarse en los valores para poder —obviando consecuencias inhumanas- desvincular protección jurídica y personalidad» (pág. 83), y reduciendo al no nacido a la condición de «valioso objeto» al no reconocérsele la condición de persona (pág. 87; cursivas en el original). 
Por otra parte, no deja de llamar la atención la manera en que el Tribunal deduce del artículo $15 \mathrm{CE}$ la consideración del feto como un bien constitucionalmente protegido. En el fundamento jurídico 4, considera pertinente traer a colación la llamada dimensión objetiva de los derechos fundamentales en virtud de la cual estos no incluyen solo derechos subjetivos de defensa sino también deberes de protección, que obligan especialmente al legislador. Pero lo que parece ignorar en sus razonamientos es que esta dimensión objetiva es consecuencia de la existencia de un derecho subjetivo previo y no una vía para negarlo. En el caso del nasciturus el Tribunal utiliza sin embargo el deber de protección como vía alternativa al reconocimiento del derecho algo que, hasta donde se me alcanza, no ha hecho con ningún otro derecho fundamen$\mathrm{tal}^{15}$. Es más, normalmente el recurso a la dimensión objetiva de los derechos fundamentales se justifica para reforzar la tutela del derecho subjetivo y no, como se ha hecho en este caso, para sustituirlo ${ }^{16}$.

Por otra parte, la solución adoptada contrasta con la generosidad —o con el carácter expansivo de la interpretación, si se prefiere- con la que el Tribunal Constitucional ha resuelto los casos de duda sobre la titularidad de derechos ${ }^{17}$, por ejemplo en relación con los extranjeros ${ }^{18}$, las personas jurídicas ${ }^{19}$ e, incluso, en algún caso, respecto de entes sin personalidad ${ }^{20}$.

iii) La constitucionalidad de los supuestos de despenalización previstos en la Ley

El Tribunal Constitucional insiste, en todo caso, en la protección que el art. 15 CE brinda a la vida en formación. No hay una desconstitucionalización de esa protección

15 Como he escrito en otro lugar, «desde el punto de vista de la dogmática de los derechos fundamentales, no resulta entendible que el bien jurídico protegido por el derecho — la vida humana o, mejor, la vida de un ser humano- se desdoble en dos contenidos distintos: un verdadero derecho subjetivo cuando se trata de la vida humana después del nacimiento, y un bien constitucionalmente protegido — sin dimensión subjetiva - cuando es la vida del nasciturus» (A.J. Gómez Montoro, «Respuestas al cuestionario», en S. Huerta Tocildo y M. Pérez Manzano (dir.), Cuestiones actuales de la Protección de la Vida y la Integridad Física y Moral, Aranzadi, Cizur Menor 2012, pág. 83).

${ }^{16}$ Distinto es el caso de bienes constitucionales en los que no hay un elemento subjetivo y que, por tanto, son difícilmente reconducibles a un derecho subjetivo: medio ambiente, cultura, patrimonio artístico, etc. Sobre la dimensión objetiva de los derechos fundamentales y los mandatos de protección que derivan de la misma vid., por todos, F. Simón Yarza, Medio ambiente y derechos fundamentales, Centro de Estudios Políticos y Constitucionales, Centro de Estudios Políticos y Constitucionales, Madrid 2012, en especial págs. 99 y sigs.

17 Vid. A.J. Gómez Montoro, «Titularidad de Derechos», en M. Aragón Reyes y C. Aguado Renedo (dir.), Derechos fundamentales y su protección. Temas básicos de Derecho Constitucional. Tomo III, Civitas, Madrid 2011, págs. 42-58.

${ }_{18}$ Véanse entre otras las SSTC 117/1985, 95/2003 y 236/2007.

19 SSTC 23/1989 y 139/1995 entre otras muchas. Vid. A.J. Gómez Montoro, «Los derechos fundamentales de las personas jurídicas. Un intento de fundamentación», en Revista Española de Derecho Constitucional, núm. 65, 2002, págs. 49-105.

${ }^{20}$ STC 214/1991. 
y ni siquiera un derecho de la madre que prevalezca incondicionalmente sino que, en la línea marcada por el Tribunal Constitucional alemán en su sentencia de $1975^{21}$, considera que hay un mandato de protección, que incluye la garantía penal, y que solo cede cuando hay otros derechos o bienes constitucionales en juego: ni la vida del nasciturus puede prevalecer incondicionalmente frente a los derechos de la mujer, ni estos pueden tener primacía absoluta. Por ello, concluye el Tribunal, «el intérprete constitucional se ve obligado a ponderar los bienes y derechos en función del supuesto planteado, tratando de armonizarlos si ello es posible o, en caso contrario, precisando las condiciones y requisitos en que podría admitirse la prevalencia de uno de ellos» (FJ 9).

Pues bien, en todos los supuestos de despenalización se alcanza la conclusión de que el legislador ha ponderado adecuadamente y se confirma, por tanto, la constitucionalidad de la ley. Llama, sin embargo, la atención el poco detenimiento con que el Tribunal lleva a cabo la ponderación; lejos de analizar con detalle cada supuesto, siguiendo los tres pasos que, según doctrina consolidada, exige toda ponderación, y el intento de armonizar los bienes y derechos en juego ${ }^{22}$, se limita a validar cada supuesto con afirmaciones categóricas, más o menos genéricas.

Así, por ejemplo, al tratar del aborto eugenésico, sostiene la sentencia que «el recurso a la sanción penal entrañaría la imposición de una conducta que excede de la que normalmente es exigible a la madre y a la familia» (FJ 11). Sin desconocer los importantes sacrificios que un hijo con graves deficiencias físicas o psíquicas lleva consigo, no parece que la referencia al hecho de que en tales casos surjan obligaciones que excedan de lo habitualmente exigible sea un parámetro por sí mismo adecuado para decidir, y en todo caso no implica una ponderación detenida ni proporcional a la grave obligación de tutela del nasciturus que, según la misma sentencia, corresponde al Estado ${ }^{23}$.

Se ha criticado, incluso en algunos de los votos particulares ${ }^{24}$, el poco peso que en la sentencia tienen los derechos de la mujer que podrían estar implicados: en

${ }^{21}$ Sentencia de 25 de febrero de 1975 (BVerfGE 39,1).

${ }^{22}$ Véase por todos, R. Alexy, Theorie der Grundrechte, Shurkamp, 3. ${ }^{a}$ ed., Frankfurt a.M., 1996. Y en España, J.M. Rodríguez de Santiago, La ponderación de bienes e intereses en el Derecho Administrativo, Marcial Pons, Madrid 2000, en especial, págs.. 118 y sigs.

${ }^{23}$ Señala también como argumento el Tribunal la insuficiencia de prestaciones estatales y sociales que, en muchos casos, acompañan a esa situación y afirma, que «en la media en que se avance en la ejecución de la política preventiva y en la generalización e intensidad de las prestaciones asistenciales que son inherentes al Estado Social (...) se contribuirá de modo decisivo a evitar la situación que está en la base de la despenalización» (FJ 11). Pero, aparte de que la realidad ha desmentido esa previsión, pues la indudable mejora en las prestaciones en los más de treinta años trascurridos no parece que haya incidido en el número de abortos, el Tribunal tampoco utiliza la existencia o no de recursos para afrontar la situación como un elemento a tener en cuenta en cada caso: la ley permite el aborto con independencia de los recursos — propios o de entidades públicas — de que puedan disponer los padres.

${ }^{24}$ En especial en el formulado por el Magistrado Rubio Llorente. Asimismo, el Magistrado Tomás y Valiente denuncia en su voto disidente la ausencia de consideraciones «sobre el primero de los que la Constitución denomina valores superiores: La libertad». 
particular el libre desarrollo de la personalidad (art. $10 \mathrm{CE}$ ) y el derecho a la intimidad (art. $18 \mathrm{CE}$ ). Y es cierto que apenas aparecen en el razonamiento del Tribunal. Quizás ello se explique porque ni el primero es considerado como un derecho en nuestra Constitución (a diferencia de lo que ocurre con el art. 2.1 de la Constitución alemana), ni la intimidad se ha entendido (ni entonces ni ahora) como un derecho a la privacidad en el sentido Norteamericano o en la manera en que el Tribunal Europeo de Derechos Humanos interpreta el derecho a la vida privada del art. 8 del Convenio ${ }^{25}$. Pero esa falta de ponderación de los posibles derechos de la mujer implicados todavía hace más llamativo el sacrificio en todos los casos de la vida del nasciturus ${ }^{26}$.

iv) Las condiciones para la constitucionalidad de la despenalización

El Tribunal da por bueno, en consecuencia, el sistema de indicaciones que permite la exclusión de la protección penal del nasciturus en tales casos «en razón de la protección de derechos constitucionales de la mujer y de las circunstancias concurrentes en determinadas situaciones». Pero no termina aquí su juicio sino que considera que el art. $15 \mathrm{CE}$ obliga al legislador a establecer un sistema que garantice que la protección del feto «no disminuya más allá de lo que exige la finalidad del nuevo precepto» (FJ 12). Y aquí concluye que no se dan esas garantías: entiende, en concreto, que en el aborto terapéutico y en el eugenésico, además de la participación del médico, debe asegurarse que la intervención se lleve a cabo en centros sanitarios autorizados al efecto. En cuanto al supuesto de violación considera que por las dificultades objetivas para la comprobación judicial con anterioridad al aborto es suficiente — pero necesaria_ la denuncia previa.

Saliendo al paso de las posibles críticas, entiende el Tribunal que estas consideraciones caen dentro de su función, que no es, desde luego, sustituir al legislador pero sí, de acuerdo con el art. 79.4 b) de su Ley Orgánica, «indicar las modificaciones que a su juicio - y sin excluir otras posibles - permitieran la prosecución de la tramitación del proyecto por el órgano competente» (FJ 12) ${ }^{27}$.

${ }^{25}$ Sobre la interpretación expansiva de este precepto por el TEDH puede verse A. J. Gómez Montoro, Vida privada y autonomía personal o una interpretación passe-partout del artículo $8 \mathrm{CEDH}$, en VV.AA., La Constitución política de España. Estudios en homenaje a Manuel Aragón Reyes, Centro de Estudios Políticos y Constitucionales, Madrid, 2016, págs. 617-650.

${ }^{26}$ El Tribunal no ha admitido hasta ahora —aunque cada vez es más propenso a ello, quizás por influencia de las decisiones del Tribunal de Estrasburgo - un derecho a la libre autodeterminación o un derecho a la libertad en general con un carácter de derecho fundamental (vid. C. Tomás-Valiente, «La jurisprudencia constitucional española sobre el aborto», cit., págs. 95 y sigs.).

27 A pesar de estas explicaciones, la forma de razonar del Tribunal fue duramente criticada en los votos particulares, en particular los de los Magistrados Tomás y Valiente y Rubio Llorente, quienes consideran que la sentencia traspasa los límites de la jurisdicción para ocupar la posición del legislador. 


\section{c) La nueva ley orgánica y su no impugnación}

Más allá de los debates que suscitó esta sentencia, el hecho es que tan solo tres meses después el legislador aprobó una nueva ley orgánica (LO 9/1985, de 5 de julio) mediante la que se introducía un nuevo art. 417 bis del Código Penal despenalizando el aborto en los mismos supuestos e introduciendo las garantías que el Tribunal había indicado. Esta nueva ley no sería ya impugnada y estuvo en vigor durante más de veinticinco años, hasta la aprobación de la LO 2/2010 a la que enseguida nos referiremos ${ }^{28}$.

\section{DEL SISTEMA DE INDICACIONES AL SISTEMA DE PLAZOS: LA LEY ORGÁNICA 2/2010, DE 3 DE MARZO, DE SALUD SEXUAL Y REPRODUCTIVA Y DE LA INTERRUPCIÓN VOLUNTARIA DEL EMBARAZO}

a) La evolución del aborto en España bajo la ley de 1985

Desde la entrada en vigor de la nueva ley, y como era previsible, el número de abortos en España fue subiendo de forma constante, pasando de 411 en 1986 a 16.206 en el año siguiente y alcanzando su culmen en 2011 con 118.359 abortos (una tasa de 12.47 sobre 1000 mujeres entre 15 y 55 años $)^{29}$. Por lo que a las causas invocadas se refiere, en torno al 97 por ciento de los abortos se justificaron por la afectación a la salud de la madre; y cerca del 3 por ciento por malformaciones en el feto, siendo el

28 De hecho este art. 417 bis del Código Penal fue una de las pocas normas que quedaron en vigor cuando se aprobó un nuevo Código mediante la LO 10/1995, de 23 de noviembre.

29 Según los datos del Ministerio de Sanidad español, la evolución de los abortos hasta 2016 (último año disponible) ha sido la siguiente:

\begin{tabular}{cccccc}
\hline Año & $\begin{array}{c}\text { Número de I.V.E. } \\
\text { (abortos inducidos) }\end{array}$ & $\begin{array}{c}\text { Tasa por 1.000 } \\
\text { mujeres }\end{array}$ & Año & $\begin{array}{c}\text { Número de I.V.E. } \\
\text { (abortos inducidos) }\end{array}$ & $\begin{array}{c}\text { Tasa por } 1.000 \\
\text { mujeres }\end{array}$ \\
\hline 1986 & 411 & 0,05 & 2001 & 69.857 & 7,66 \\
1987 & 16.206 & 1,96 & 2002 & 77.125 & 8,46 \\
1988 & 26.069 & 3,11 & 2003 & 79.788 & 8,77 \\
1989 & 30.552 & 3,61 & 2004 & 84.985 & 8,94 \\
1990 & 37.231 & 4,35 & 2005 & 91.664 & 9,60 \\
1991 & 41.910 & 4,79 & 2006 & 101.592 & 10,62 \\
1992 & 44.962 & 5,10 & 2007 & 112.138 & 11,49 \\
1993 & 45.503 & 5,15 & 2008 & 115.812 & 11,78 \\
1994 & 47.832 & 5,38 & 2009 & 111.482 & 11,41 \\
1995 & 49.367 & 5,53 & 2010 & 113.031 & 11,71 \\
1996 & 51.002 & 5,69 & 2011 & 118.359 & 12,47 \\
1997 & 49.578 & 5,52 & 2012 & 112.390 & 12,12 \\
1998 & 53.847 & 6,00 & 2013 & 108.690 & 11,74 \\
1999 & 58.399 & 6,52 & 2014 & 94.796 & 10,46 \\
2000 & 63.756 & 7,14 & 2015 & 94.188 & 10,40 \\
& & & 2016 & 93.131 & 10,36 \\
\hline
\end{tabular}


caso de violación totalmente marginal (no llega habitualmente al 0,05 por ciento) ${ }^{30}$. No hay constancia de que en ningún caso se rechazara la solicitud y se ha llamado la atención sobre el escasísimo número de diligencias previas para investigar posibles incumplimientos de la ley, que no llegan al 0,1 por ciento de los abortos ${ }^{31}$. Lo que hace ver que, aunque estábamos ante un sistema de indicaciones, en realidad ha funcionado como un sistema sin apenas restricciones ${ }^{32}$.

\section{b) Los argumentos para la reforma y el contexto de la nueva regulación}

A pesar de ello, y tras las elecciones de 2004, el Gobierno presidido por Rodríguez Zapatero, del partido socialista, impulsó — - según lo previsto en su programa electoral - una nueva ley basada en un sistema de plazos. La nueva regulación no se hizo ya mediante la reforma del Código Penal sino en el marco de una legislación sobre salud sexual, la Ley Orgánica $2 / 2010$, de 3 de marzo, de salud sexual y reproductiva y de la interrupción voluntaria del embarazo.

En el extenso preámbulo de la ley se exponen de manera clara las razones que llevan a su aprobación y los presupuestos ideológicos en que se inspira. El punto de partida es muy distinto al de la normativa anterior, que se enmarcaba en el ámbito de la protección penal de la vida. Ya no se insiste en el deber del Estado, derivado del art. $15 \mathrm{CE}$, de proteger la vida en formación sino que se parte de la libre autodeterminación de la mujer y de sus derechos sexuales y reproductivos ${ }^{33}$, dentro de los cuales está «la decisión de tener hijos y cuándo tenerlos» ${ }^{34}$. La protección de esa autonomía personal se vincula, con la necesidad de luchar contra la discriminación de las mujeres, "para quienes el embarazo y la maternidad son hechos que afectan profundamente a sus vidas en todos los sentidos». Se invocan algunos instrumentos internacionales - la Convención de Naciones Unidas sobre la eliminación de todas

${ }^{30}$ Los datos entre 2001 y 2010, antes de entrar en vigor la nueva ley, pueden consultarse en https:// www.msssi.gob.es/profesionales/saludPublica/prevPromocion/embarazo/docs/IVEs_anteriores/IVE_2010. pdf, pág. 19. Tras la entrada en vigor de la nueva ley la causa principal es la petición de la mujer, seguida muy de lejos por el riesgo para la salud o la vida de la embarazada o las anomalías fetales (por ejemplo, en 2013 las cifras eran 89,9 por ciento para el primer caso, 6,9 por ciento para el segundo y 3,1 para el tercero).

31 Vid. P. Sánchez-Ostiz, « ¿Tienen todos derecho a la vida? Bases para un concepto constitucional de persona», cit., pág. 3 .

32 Como escribió en 2007 J.M. Silva Sánchez, «veinte años después de la despenalización del aborto mediante un sistema de indicaciones aplicado de forma laxa hasta el extremo, se observa un fracaso absoluto en la protección jurídica (y extrajurídica) de la vida del concebido y no nacido» («Los indeseados como enemigos. La exclusión de seres humanos del status personae», cit., pág. 5).

33 El nuevo enfoque se concreta también en el articulado de la ley: así, según su art. 12 las condiciones de acceso a la interrupción del embarazo «se interpretarán en el modo más favorable para la protección y eficacia de los derechos fundamentales de la mujer que solicita la intervención».

34 Desde luego nada hay que objetar a estar afirmación. Lo que ocurre, como es obvio, es que jurídicamente esa decisión no plantea los mismos problemas antes de un embarazo que cuando existe ya una vida en formación sobre la que se extiende la protección del art. $15 \mathrm{CE}$. 
las formas de discriminación contra la Mujer (1979), la Plataforma de Acción de Beijing acordada en la IV Conferencia de Naciones Unidas sobre la Mujer (1995), la Convención sobre los Derechos de las personas con discapacidad (2006) o la Resolución 2001/2128 del Parlamento Europeo sobre salud sexual y reproductiva y los derechos asociados - y la necesidad de adaptar la regulación española al «consenso de la comunidad internacional en esta materia».

Se justifica, además, la nueva ley en algunas afirmaciones un tanto apodícticas que, cuanto menos, resultan llamativas. De un lado, se sostiene la necesidad de aportar certeza y seguridad ya que la aplicación de la ley anterior habría generado «incertidumbre y prácticas que han afectado a la seguridad jurídica, con consecuencias tanto para la garantía de los derechos de las mujeres como para la eficaz protección del bien jurídico penalmente tutelado». Pero, durante las más de tres décadas de vigencia de la ley anterior no parece que haya habido otra inseguridad que la lógica de garantizar que no se destruye la vida del nasciturus más que en los casos legalmente previstos; y desde luego, no se entiende cómo la mayor seguridad jurídica que ofrece la ley de plazos puede incidir en una mayor protección del bien jurídico penalmente tutelado ${ }^{35}$.

Por otra parte, se intenta mostrar que la ley es respetuosa con la doctrina del Tribunal Constitucional sentada en la sentencia 53/1985 pero se afirma que «el legislador ha considerado razonable, de acuerdo con las indicaciones de las personas expertas y el análisis del derecho comparado, dejar un plazo de catorce semanas en el que se garantiza a las mujeres la posibilidad de tomar una decisión libre e informada sobre la interrupción del embarazo, sin interferencia de terceros». Se sostiene, asimismo, que «la experiencia ha demostrado que la protección de la vida prenatal es más eficaz a través de políticas activas de apoyo a las mujeres embarazadas y a la maternidad». Está claro sin embargo que es un cambio relevante respecto del sistema de indicaciones; en cuanto a la segunda de las afirmaciones, no se aportan evidencias de que eso sea así y, en todo caso, la ley no contiene ninguna de esas políticas de apoyo a la mujer embarazada y la maternidad.

\section{c) La nueva regulación}

De acuerdo con la nueva ley, el aborto es posible por la sola decisión de la mujer dentro de las catorce primeras semanas siempre que se le haya informado de los derechos, prestaciones y ayudas públicas de apoyo a la maternidad y hayan trascurrido tres días desde esa información (art. 14).

35 No pocos autores han insistido también en el argumento de la seguridad jurídica e incluso de la igualdad, en la medida en que se pueden iniciar investigaciones policiales y judiciales sobre el cumplimiento de la legalidad y estas pueden darse en unos casos y otros no (vid., por ejemplo, A. Ruiz Miguel, El aborto: Problemas constitucionales, Centro de Estudios Constitucionales, Madrid 1990, págs. 13 y sigs.). El razonamiento no deja de llamar la atención pues lo mismo se puede decir de cualquier delito; y de hecho, la presunta desigualdad tampoco desaparecería con una ley de plazos una vez pasadas las semanas en las que la decisión de abortar es libre. 
Trascurrido el plazo de catorce semanas y siempre que no se superen las veintidós semanas de gestación el aborto es posible por causas médicas. En concreto: a) Cuando exista grave riesgo para la vida o la salud de la embarazada [art. 15 a)]; y b) Cuando exista riesgo de graves anomalías en el feto [art. 15 b)].

Por último, el aborto será posible en cualquier momento de la gestación cuando se detecten anomalías fetales incompatibles con la vida o una enfermedad extremadamente grave e incurable [art. 15 c)]. En este último caso, es necesario que la decisión sea confirmada por un comité clínico integrado por dos médicos especialistas en ginecología o diagnóstico prenatal y un pediatra (art. 16).

Uno de los aspectos más polémicos de la ley fue la regulación del aborto de chicas menores de edad — menos de 18 años- pero mayores de 16. Según el apartado cuarto del art. 13, a ellas les corresponde exclusivamente el consentimiento para la interrupción voluntaria del embarazo, debiendo informar a uno de los dos representantes legales, padre o madre. Pero incluso se podrá prescindir de esa información cuando la menor alegue que provocará un conflicto grave con peligro de violencia, amenazas, malos tratos o una situación de desamparo.

El art. 19.2 prevé la objeción de conciencia en términos considerablemente restringidos: solo puede ser invocada por los profesionales sanitarios directamente implicados y sin que la calidad de la prestación pueda ser menoscabada. Cabe, por último, destacar que la ley impone que la formación de profesionales de la salud se lleve a cabo con perspectiva de género y exige que los programas curriculares de carreras relacionadas con la medicina y ciencias de la salud incluyan la formación en la práctica clínica de abortos (art. 8).

\section{UN DEBATE ABIERTO}

\section{a) Las dudas sobre la constitucionalidad de la Ley}

A pesar del empeño de la Ley por presentarse como respetuosa de la doctrina de la STC 53/1985, y aunque un importante sector doctrinal no tienen dudas sobre su constitucionalidad $^{36}$, creo que es difícil admitir su compatibilidad en algunos extre-

36 Vid., por ejemplo, A. Ruiz Miguel, El aborto: Problemas constitucionales, cit., págs.. 89 y sigs.; M. Pérez Manzano y C. Tomás-Valiente, «Comentario al art. 15» en M.E Casas Baamonde y M. RodríguezPiñero y Bravo-Ferrer, Comentarios a la Constitución Española, Wolters-Kluwer, Madrid, 2008, pág. 314; J.C. Martorell Mateu, «La regulación involuntaria del embarazo», en S. Huerta Tocildo y M. Pérez Manzano (dir.), Cuestiones actuales de la Protección de la Vida y la Integridad Física y Moral, cit., págs. 63-64) o M.L. Cuerda Arnau (id., págs. 70-71). Es también de esta opinión P. de Lora Deltoro en su trabajo «Abortar y dar vida. ¿Es constitucional la Ley 2/2010?», recogido en el mismo volumen (págs. 92-109), aunque el autor no deja de reconocer que hay en la STC 53/1985 argumentos para declarar inadmisible el modelo instaurado en la nueva ley y desarrolla, sobre todo, un argumento distinto, en su opinión no suficientemente valorado por la STC 53/1985, «la dimensión 'igualitaria’ de la interrupción del embarazo» (págs. 93 y sigs.). 
mos con la jurisprudencia constitucional (lo que no significa, evidentemente, que el Tribunal no pueda de hecho cambiar esa jurisprudencia). Como hemos visto, la STC 53/1985 parte de la obligación constitucional del legislador de proteger la vida, también mediante la tutela penal; una tutela que se puede excluir cuando haya motivos concretos y graves que lo justifiquen y siempre que se establezcan garantías para asegurar que no habrá abortos legales fuera de esos supuestos. En la nueva regulación, el legislador adopta una perspectiva muy distinta dando preferencia absoluta a la libertad de decisión de la mujer en las catorce primeras semanas, sin que sean siquiera relevantes las razones que le llevan a decidir el aborto, y exigiendo unas garantías muy pequeñas ${ }^{37}$.

Mientras que en un sistema de indicaciones es el legislador el que pondera los supuestos en los que la no punibilidad es posible, en la nueva regulación el legislador decide que durante las catorce primeras semanas la vida del nasciturus cede siempre frente a la voluntad de la madre (cualesquiera que sean las concretas circunstancias que conducen a la decisión de abortar), lo que implica una abdicación total de su deber de protección. Y esto en aras de un derecho a decidir de la mujer que no tiene apoyo expreso en al Constitución sino que se construye a partir de algunos derechos, ciertamente existentes pero con otros contenidos (intimidad, derecho a la maternidad...) y del principio — que no derecho en nuestro ordenamiento- del libre desarrollo de la personalidad, y que se configura además en términos casi absolutos durante las catorce primeras semanas ${ }^{38}$.

El único límite a la voluntad de la madre es de naturaleza procedimental: la información que debe recibir antes del consentimiento, una información que, además,

37 Está por ver el peso que pueda tener en la decisión del Tribunal Constitucional la jurisprudencia del Tribunal Europeo de Derechos Humanos. En los últimos años, a pesar de reconocer que no existe en el Convenio un derecho al aborto y haber remitido la cuestión de cuándo comienza la vida humana al margen de apreciación de los Estados, viene considerando que la decisión sobre el aborto, sobre todo cuando se pide por razones de salud o bienestar de la madre, afecta al derecho a la vida privada del art. 8 del Convenio, y se aprecia una tendencia cada vez más expansiva a condenar a los Estados que dificultan el acceso al aborto (véanse, por ejemplo, Tysiac c. Polonia, de 2007, A, B y C c. Irlanda, de 2010, o P, S y C c. Polonia, de 2012). Creo, sin embargo, que no existen en sus pronunciamientos razones que lleven a una valoración positiva de un sistema de plazos (véanse F. Rey, «La protección jurídica de la vida ante el Tribunal de Estrasburgo: un derecho en transformación y expansión», Revista Europea de Derechos Fundamentales, núm. 12, 2008, págs. 56 y sigs. y A. J. Gómez Montoro, «Vida privada y autonomía personal o una interpretación passe-partout del art. $8 \mathrm{CEDH»,} \mathrm{cit.,} \mathrm{págs.} 635$ y sigs.).

38 Como recordó G. Rodríguez Mourullo, el sistema de plazos implica una desprotección del nasciturus que resulta incongruente con la admisión de la vida del concebido con un bien jurídico al dejar a la libre decisión de la embarazada la interrupción del embarazo sin alegar motivo o fundamento para ello (cfr. «Comentario al art. 15 de la Constitución», cit., págs. 278 y sigs.). Para L.M. Díez-Picazo el sistema de plazos casa mal con la doctrina jurisprudencial establecida por la STC 53/1985; ello requeriría encontrar valores constitucionales relevantes distintos a los tenidos en cuenta en esa sentencia y que, en último término, llevaría a configurar la interrupción voluntaria del embarazo como un derecho «lo que supondría un cambio radical en la solución del problema constitucional del aborto» (Sistema de derechos fundamentales, Civitas, 4. . ed., Madrid 2013, pág. 208. 
está muy lejos del tipo de asesoramiento previsto, por ejemplo, en la legislación alemana. Mientras que el art. 17.1 de la Ley obliga a dar información - parece que de palabra - sobre los distintos métodos de interrupción del embarazo, las condiciones previstas en la ley, los centros públicos y acreditados, etc., según su apartado 2 la información sobre las alternativas al aborto se da por escrito, en un sobre cerrado (es decir, ni siquiera se exige una conversación, ni se garantiza que la mujer conocerá efectivamente el contenido del sobre), y no incluye ninguna referencia al valor de la vida humana y su carácter de bien constitucional.

Esa omisión de cualquier referencia al valor de la vida es una constante en la Ley; así, resulta altamente significativo que entre las políticas públicas y la medidas de tipo educativo que recoge el Título I no haya una sola mención a la importancia de la vida humana ni medida alguna encaminada a sensibilizar sobre la gravedad del aborto y la existencia de vías alternativas al mismo una vez que se ha producido el embarazo.

Algunas de estas dudas sobre la constitucionalidad de la nueva norma motivaron el recurso de inconstitucionalidad interpuesto por 71 diputados del Partido Popular, el 1 de junio de 2010, contra varios de los artículos de la Ley. A pesar del tiempo transcurrido - y de que en el ATC 90/2010, de 14 de julio, el Tribunal decidió dar «carácter prioritario a la tramitación y resolución» de dicho recurso (fundamento jurídico 3, in fine), aún no se ha dictado sentencia, por lo que las dudas siguen existiendo.

\section{b) La fallida reforma de la Ley}

Quizás una de las razones inconfesadas del retraso del Tribunal para resolver el recurso contra una ley tan relevante —además de la excesiva demora con que generalmente resuelve la mayor parte de los asuntos- es el hecho de que en las elecciones de 2011 el Partido Popular obtuviera la mayoría absoluta, lo que le permitía reformar la Ley tal y como había prometido en su programa electoral. De hecho, al poco tiempo de formarse el Gobierno el Ministro de Justicia anunció una reforma que debería volver al sistema de indicaciones e incluso con algunas restricciones. El anteproyecto, que pretendía no solo regular el aborto sino que se presentaba como una ley para la protección de la vida del concebido y de los derechos de la mujer embarazada ${ }^{39}$, fue aprobado por el Gobierno el 20 de diciembre de 2013 e

39 No deja de llamar la atención el escaso énfasis que se pone, tanto en la legislación como en los programas de los partidos, en este tipo de medidas que ayuden a la mujer a superar el conflicto que conduce a un aborto. Aunque buena parte de los partidarios del aborto consideran que es una solución no deseable, sin embargo con no poca frecuencia se reacciona de manera adversa frente a ese tipo de propuestas. Una excepción en el panorama español fue la Ley de las Cortes Valencianas 6/2009, de 30 de junio, de protección de la maternidad, que establecía medidas para ayudar a la mujer gestante a seguir adelante con su embarazo; pero la ley fue contestada políticamente y derogada en cuanto hubo un cambio de mayoría en las Cortes Valencianas. 
incluso fue informado por el Consejo General del Poder Judicial. Sin embargo, el 23 de septiembre de 2014 y ante las reacciones adversas de los partidarios del aborto, el Presidente del Gobierno anunció que renunciaba a esa reforma y solo se procedió a modificar el artículo relativo al aborto de menores de 16 y 17 años, que había sido según se ha visto uno de los puntos especialmente polémicos de la ley ${ }^{40}$. El 21 de septiembre se aprobó la Ley Orgánica 11/2015 para reforzar la protección de las menores y mujeres con capacidad modificada judicialmente en la interrupción voluntaria del embarazo. La nueva ley deroga las previsiones sobre el consentimiento de las menores de la LO 2/2012 y remite a la legislación general sobre autonomía del paciente estableciendo que la interrupción voluntaria del embarazo de menores de edad o personas con discapacidad requerirá el consentimiento expreso de sus representantes legales. Y en caso de conflicto se resolverá de acuerdo con al legislación general, contenida en el Código Civil.

\section{LA DESPROTECCIÓN DEL EMBRIÓN EN LAS LEYES SOBRE FECUNDACIÓN IN VITRO Y SOBRE EL USO DE TEJIDOS Y ÓRGANOS EMBRIONARIOS Y LAS SSTC 212/1996 Y 116/1999}

\section{a) Las Leyes 35/1988, sobre técnicas de reproducción asistida y 42/1988, de donación y utilización de embriones y fetos bumanos o de sus células, tejidos u órganos}

Junto con la STC 53/1985, los otros dos leading cases sobre el estatus de la vida en formación son las SSTC 212/1996 y 116/1999, relativas no ya al aborto sino a los problemas que plantea la fecundación in vitro, con la consiguiente generación de embriones, así como al posible uso de los órganos y tejidos de los llamados embriones «no viables» con fines terapéuticos y de investigación. Aunque las dos sentencias están separadas en el tiempo por dos años y medio, se refieren en realidad a dos leyes aprobadas casi a la vez y que, en todo caso, plantean algunos problemas comunes ${ }^{41}$ : La Ley 35/1988, de 22 de noviembre, sobre técnicas de reproducción asistida (cuya constitucionalidad se examina en la STC 116/1999) y la Ley 42/1988, de 28 de

${ }^{40}$ Esa decisión provocó la renuncia del Ministro de Justicia, Alberto Ruiz Gallardón, impulsor de la ley.

${ }^{41}$ En el origen de la nueva legislación está un informe elaborado por una Comisión Especial de Estudio de la Fecundación In Vitro y la Inseminación Artificial Humanas, constituida por el Congreso de los Diputados, y presidida por el Diputado y médico Marcelo Palacios (de aquí que se hable con frecuencia del Informe Palacios). Vid., con valoraciones muy distintas, A. Calvo Meijide, «El permisivismo en la FIV: b) El informe Palacios, fundamento de la legislación española» en J. Ballesteros (coord.), La humanidad in vitro, Comares, Granada 2002, págs. 63 y sigs. y J.A. Souto $\mathrm{Paz}$ «El informe Palacios y la ley de reproducción asistida», en A. Díaz Martínez (coord.), Régimen jurídico-privado de la reproducción asistida en España: el proceso legal de reformas, Dykinson, Madrid 2006, págs. 187-196. 
diciembre, de donación y utilización de embriones y fetos humanos o de sus células, tejidos u órganos (a la que se refiere la STC 212/1996) ${ }^{42}$.

La primera de las leyes abordó por primera vez en España las técnicas de reproducción asistida. Se regula, en concreto, la inseminación artificial, la fecundación in vitro, con transferencia de embriones, y la transferencia intratubárica de gametos. Entre los principios generales (Capítulo II) cabe destacar la prohibición de fecundación de óvulos humanos con cualquier fin distinto a la procreación humana (art. 3), la previsión de que se transferirán al útero solo el número de preembriones considerado científicamente más adecuado (art. 4) y la posibilidad de que la mujer receptora pida — de forma vinculante — la suspensión del procedimiento en cualquier momento de su realización (art. 2.4).

Se regula asimismo la donación, que será siempre anónima (art. 5.5) y no podrá tener carácter lucrativo o comercial (art. 5.3). Y en cuanto a las usuarias, se incluye a toda mujer mayor de edad y con plena capacidad de obrar (art. 6.1), esté casada o no, si bien en el primer caso se requerirá el consentimiento del marido (art. 6.3). Contiene también la ley previsiones sobre la filiación de los nacidos mediante estas técnicas (arts. 7 a 10).

Especial interés tienen para el objeto de este trabajo las disposiciones sobre crioconservacion (art. 11, en especial la previsión de su apartado tercero de que los embriones sobrantes se conservarán en bancos autorizados por un máximo de cinco años), sobre diagnóstico y tratamiento (art. 12 y 13) y sobre investigación y experimentación (arts. 14 a 17). Se contienen, asimismo, disposiciones sobre los requisitos que deben reunir los centros sanitarios y los equipos biomédicos que realicen estas técnicas (arts. 18 y 19), y sobre la creación de la Comisión Nacional de Reproducción Asistida (art. 21). Y se establece un régimen de infracciones y sanciones (art. 20), únicamente de índole administrativa.

Por lo que se refiere a la Ley 42/1988, de donación y utilización de embriones y sus órganos y tejidos, es mucho más breve. Prohíbe toda actividad y utilización de carácter lucrativo o comercial [art. 2 d)] y exige que los embriones o fetos objeto de la donación «sean clínicamente no viables o estén muertos» [art. 2.e)]. Prohíbe el aborto que tenga como finalidad la donación y utilización posterior de embriones o fetos (art. 3.2) y establece los criterios para poder actuar sobre los mismos (art. 6), así como su uso para la investigación y experimentación (arts. 7 y 8). Por último, el art. 9 establece un régimen de infracciones y sanciones que también en este caso son solo administrativas, excluyendo la sanción penal.

Ambas leyes fueron recurridas antes el Tribunal Constitucional por Diputados del Partido Popular, impugnaciones que fueron resueltas por las SSTC 212/1996 y 116/1999. Parte de la problemática que plantean es común, lo que aconseja un

${ }^{42}$ Una vez más el Tribunal Constitucional tardó un tiempo a todas luces improcedente para resolver un recurso (casi ocho años en un caso y once en otro), máxime en materias de tanta relevancia. Como, además, la Constitución española no prevé la posibilidad de suspender la ley durante la tramitación del recurso, esto favorece la consolidación de situaciones por la vía de hecho. 
tratamiento conjunto de las mismas, sin perjuicio de señalar lo que de específico tiene cada una ${ }^{43}$. Ambas sentencias declaran básicamente constitucionales las leyes impugnadas. En los dos casos solo hay una declaración de inconstitucionalidad por infracción del principio de legalidad sancionadora ${ }^{44}$ y una decisión interpretativa de otros dos preceptos en el sentido de que la remisión que las leyes hacen a la normativa legal debe ser entendida como una remisión a los supuestos de aborto no punible del art. 417 bis del Código Penal ${ }^{45}$. Más allá del resultado final, llama la atención la escasa profundidad con que son tratados buena parte de los problemas que se suscitan, algunos de ellos de gran calado tanto jurídico como ético. Como trataremos de exponer a continuación, en no pocas ocasiones el Tribunal resuelve las cuestiones con afirmaciones categóricas y escasamente evidentes que dejan al lector la sensación de estar más ante decisiones voluntaristas que ante razonamientos jurídico-constitucionales.

\section{b) Negación del derecho a la vida del embrión y consecuencias de su consideración como bien jurídico constitucionalmente protegido}

i) El embrión no es titular del derecho a la vida

En las dos impugnaciones se alegaba la inconstitucionalidad de la ley en su conjunto por infringir la reserva a ley orgánica que el art. $81 \mathrm{CE}$ establece para el desarrollo de los derechos fundamentales. El Tribunal desestima la alegación por considerar que del derecho a la vida «como tal y con arreglo a la STC 53/1985, son titulares los nacidos, sin que quepa extender esta titularidad a los nascituri». Por ello, «no se encuentra implicado el derecho fundamental de todos, es decir, de los nacidos, a la vida» (STC 212/1996, FJ 3. ${ }^{\circ}$ ); afirmaciones que se reiteran en los

43 Si bien el núcleo de las sentencias se centra en cuestiones relativas a la vida en formación, se suscitan también cuestiones de interés que, sin embargo, exceden del objeto de este trabajo y por tanto no se tratarán. En concreto, la STC 212/1999 incluye importantes consideraciones sobre el concepto constitucional de familia (FJ 15) y la problemática que plantea el anonimato de la donación en relación con las posibilidades de investigación de la paternidad que garantiza el art. 39.2 CE (FJ 16). Ambas sentencias analizan asimismo cuestiones relativas al alcance de la reserva de ley y la posibilidad de regulación por parte del Gobierno que, si bien indirectamente tienen que ver en la protección del embrión, tienen menos interés a los efectos de este trabajo.

44 Al tratar del régimen de infracciones y sanciones, los arts. 9.1 de la Ley 42/1988 y 20.1 de la Ley 35/1988 hacían una remisión a la Ley General de Sanidad con las adaptaciones que la materia requiriera. El Tribunal entiende que este ultimo inciso deja en la más absoluta indeterminación el régimen sancionador y resulta, por ello, contrario al art. 25.1 CE.

45 Se trata de los arts. 5.1 de la Ley 42/1988 y 12.2 de la Ley 35/1988 que declaran que las actuaciones sobre los embriones en el útero solo podrá ser de carácter diagnóstico y en beneficio del nasciturus o de conformidad con la normativa vigente. Como se acaba de indicar, señala el Tribunal en los dos casos que esa normativa no puede ser otra que la que regula los supuestos de despenalización del aborto (FFJJ 12 de la STC 212/1996 y de la STC 116/1999). 
fundamentos jurídicos 4 y 5 de la STC 116/199946. En consecuencia, el parámetro que, según el Tribunal, debe tener en cuenta para resolver las impugnaciones no es la titularidad del derecho sino las obligaciones de protección que se derivan del art. $15 \mathrm{CE}^{47}$.

ii) Dos nuevas categorías — preembriones y embriones no viables - y su relevancia jurídica

Por lo que a la ley de donación de embriones y sus tejidos se refiere, resuelve el Tribunal su posible colisión con las exigencias derivadas del art. 15 CE mediante la formulación de una nueva categoría, la de «embrión no viable». La ley no es inconstitucional, se afirma en la STC 212/1996, FJ 5, porque «parte de un presupuesto fundamental, implícito pero no por ello menos constante, cual es el carácter, cuando menos, no viable de dichos embriones y fetos humanos», carentes por tanto del presupuesto que hace de ellos un bien jurídico cuya protección encuentra fundamento en el art. $15 \mathrm{CE}$; «no cabe otorgarles el carácter de nascituri toda vez que eso es lo que se quiere decir con la expresión "no viables", que nunca van a "nacer"».

A la misma noción de inviabilidad recurre la STC 116/1999 para salvar la constitucionalidad de los arts. 15 y 16 de la Ley de fecundación asistida, relativos a la investigación o experimentación, en este caso sobre preembriones ${ }^{48}$. Este último concepto es utilizado por la ley y, según afirma en su Exposición de Motivos, «generalmente se viene aceptando el término preembrión, también denominado embrión preimplantatorio, por corresponderse con la fase de preorganogénesis, para designar el grupo de células resultantes de la división progresiva del óvulo desde la fecundación hasta aproximadamente catorce días más tarde, cuando anida establemente

46 Ya hemos visto, sin embargo, que la STC 53/1985 no justifica —al menos no suficientemente en nuestra opinión - la exclusión de los nascituri de los titulares del derecho poniendo el énfasis en que, en todo caso, vienen protegidos por el art. $15 \mathrm{CE}$. Estas nuevas sentencias vienen a poner de relieve precisamente algunas de las importantes diferencias que lleva consigo la opción por una u otra fórmula.

47 Puede verse también afectada la dignidad humana del art. 10.1 CE y, como se ha señalado con acierto, no existe tampoco obstáculo alguno para entender que la Constitución protege no solo la vida del concebido y no nacido sino también su integridad y salud, garantizadas en el mismo art. $15 \mathrm{CE}$, y debería plantearse en qué medida esa protección debe extenderse al embrión generado in vitro, algo que sin embargo quedó totalmente al margen en las sentencias (cfr. P.J. Femenía López, Status jurídico del Embrión humano, con especial consideración al concebido in vitro, cit., págs. 225 y sigs.).

48 Como ha puesto de relieve L.M Díez-Picazo, «esta regulación legal plantea no pocos problemas. Así, a parte de que no siempre es fácil determinar si un embrión es viable, hay un alto riesgo de fraude tanto por la posibilidad de enmascarar abortos ilegales, como por la tentación de producir más embriones de los necesarios para la reproducción asistida» (Sistema de derechos fundamentales, cit., pág. 215). 
en el interior del útero acabado el proceso de implantación que se inició días antes ${ }^{49}$. En una interpretación cuasi-reconstructiva del art. 15 de la Ley, entiende el Tribunal que esta excluye la experimentación con preembriones viables ${ }^{50}$, siendo entonces aplicable la doctrina de la STC 212/1996 a la que acabamos de hacer referencia y que cita literalmente el Tribunal. Por ello, sostiene, los preceptos de la ley no «pueden suscitar dudas desde el punto de vista de su adecuación al sistema constitucionalmente exigible de protección de la vida humana» [FJ 9 C)].

En su voto particular a la STC 212/1996 critica el Magistrado Gabaldón López (que rechaza además la construcción que niega al nasciturus el derecho a la vida) esta nueva categoría de «embriones no viables». En su opinión, la distinción que procede es entre embriones muertos o vivos y estos deberían protegerse en los términos que estableció la STC 53/1985. «Si ha de protegerse la vida —afirma—, el único término de exclusión será el de que se trate de organismo en que ya no hay vida. Mientras la haya, es decir, mientras no pueda decirse que falta y por consiguiente que están muertos, los embriones y fetos no viables tienen vida incluso aunque no tengan esperanza razonable de seguir viviendo» (núm. 4).

Resulta difícil negar que, efectivamente, tanto el legislador como el Tribunal Constitucional introducen un concepto nuevo o, si se prefiere, un nuevo estado entre la vida y la muerte que suscita no pocos interrogantes. Al menos, supone un paso más respecto de lo señalado en la STC 53/1985: de acuerdo con esta, la vida humana en todos sus estadios requiere la protección, incluso penal, por parte del Estado; ahora estamos ante vida humana que, o bien por razones naturales o bien porque ha sido generada artificialmente sin voluntad de hacerla viable mediante su implantación en el útero de la mujer, no podrá sobrevivir o, incluso, llegar a nacer ${ }^{51}$.

49 Véase una fundada crítica al concepto en P.J. Femenía López, Status jurídico del Embrión humano, con especial consideración al concebido in vitro, cit., págs. $12-15$ y 259 y sigs. Denuncia este autor el intento de extraer consecuencias jurídicas de unos cambios que, en realidad, no son capaces de ocultar «un proceso de vida marcado por la continuidad»: «el término preembrión sirve como límite lingüístico a la fractura que se quiere crear en la representación de las diferentes fases del desarrollo prenatal. Se espera que a una denominación diferente corresponderá una realidad también diferente» (págs. 12 y 13). Véanse asimismo, entre otras muchas, las críticas de A Ollero, Bioderecho. Entre la vida y la muerte, cit., págs. 164 y sigs. y V. Bellver, «El estatuto jurídico del embrión», en J. Ballesteros (coord.), La bumanidad in vitro, cit., págs. 255 y sigs.

50 En el art. 15 de la Ley se hace referencia a las condiciones para autorizar la «investigación con embriones viables»; entiende sin embargo el Tribunal que «si bien no es afortunada, desde la perspectiva de técnica legislativa, la redacción del precepto, un adecuado entendimiento del mismo, atendiendo el contexto normativo en que se halla situado, permite alcanzar la conclusión de que los preembriones obtenidos por fecundación in vitro solo pueden ser utilizados con fines científicos de experimentación si no son viables y siempre que, con base en los oportunos protocolos experimentales, se acredite que el modelo animal no es apto para alcanzar el fin perseguido, y así lo autorice la competente autoridad administrativa o por delegación, la Comisión Nacional multidisciplinar» (STC 116/1999 FJ 8).

51 Como señala A. Ollero, con la fecundación in vitro se produce un significativo cambio: antes el embrión era viable salvo que hubiera un insalvable obstáculo natural, ahora estamos ante una viabilidad 
En todo caso, y como se puso de relieve en un temprano comentario de la STC 212/1996 ${ }^{52}$, el Tribunal debería haber analizado si la protección de la vida que ofrece el art. 15 CE se extiende o no a esos embriones vivos, aunque no viables y, en caso afirmativo, haber ponderado si la afectación que para los mismos implican las medidas de la ley pueden justificarse por otros derechos o principios de la misma índole. Por otra parte, y como ha señalado C.M. Romeo Casabona, la sentencia no deja claro si la viabilidad es un término estrictamente biológico (incapacidad de continuar el proceso de división celular), o si se extiende también a supuestos de otra índole (como el desistimiento o imposibilidad de los progenitores de seguir adelante $)^{53}$.

Un paso más en la desprotección se da en el supuesto de embriones fecundados in vitro no transferidos. Se afirma en la STC 116/1999, fundamento jurídico 12 , que «los preembriones in vitro no gozan de una protección equiparable a la de los ya transferidos al útero materno», lo que le permite al Tribunal declarar la constitucionalidad del llamado diagnóstico preimplantatorio (art. 12). Sin embargo, puesto que los dos son seres humanos vivos, la viabilidad y, con ella, la diferencia de trato (protección constitucional en un caso y posibilidad de destrucción con fines de experimentación en el otro), no depende de la biología o de otros factores externos sino simplemente de la decisión de los progenitores de proceder o no a la implantación ${ }^{54}$. Y, desde luego, tratándose de una técnica que puede tener como consecuencia la «selección» de embriones y la no trasferencia de aquellos que presenten enfermedades, se echan en falta consideraciones sobre la dignidad de la persona.

dependiente, solo la acción el hombre mediante la implantación lo hace viable (Bioderecho. Entre la vida y la muerte, cit., pág. 26). Sobre las dificultades que plantea la condición de viabilidad, vid. P.J. Femenía López, Status jurídico del Embrión bumano, con especial consideración al concebido in vitro, cit., págs. 264 y sigs.

52 J. Pardo Falcón, «A vueltas con el artículo 15 CE y otras cuestiones más o menos recurrentes de nuestro Derecho Constitucional (un comentario a la STC 212/1996 de 19 de diciembre)», Revista Española de Derecho Constitucional, núm. 51, 1997, págs. 257-258).

53 «El derecho a la vida: aspectos constitucionales de las nuevas biotecnologías», en El derecho a la vida. Actas de las VIII Jornadas de la Asociación de Letrados del Tribunal Constitucional, CEPC, Madrid 2003, págs. 35 y sigs. Duda que es resuelta por este autor en el sentido de considerar que la única interpretación plausible de la ley es la que identifica la inviabilidad con razones estrictamente biológicas. De la misma opinión es F.J. Díaz Revorio, «Bioética y valores constitucionales en el comienzo de la vida humana», en M. Gascón Abellán, M.C González Carrasco y J. Cantero Martínez (coord.), Derecho sanitario y bioética, Tirant lo Blanch, Valencia 2011, pág. 809.

${ }^{54}$ Además, y como ha sido puesto de relieve, no deja de haber en la ley importantes contradicciones: si el criterio legal es que los embriones no trasplantados al útero no merecen protección, no se entiende por que no se permite la experimentación una vez sobrepasado el plazo de 14 días; si por el contrario el criterio legal es que la vida empieza con la fecundación, no se entiende que se permita su destrucción. $\mathrm{Y}$ es que, «a partir del día catorce al embrión fecundado in vitro nada le acontece como para variar su estatuto» (P.J. Femenía López, Status jurídico del Embrión humano, con especial consideración al concebido in vitro, cit., págs. 259-260). 
iii) Los embriones sobrantes

Una problemática especial plantea la opción del legislador de permitir que se fecunden más embriones de los que se transferirán al útero de la mujer. Esto da lugar a lo que el art. 11.3 de la Ley llama «preembriones sobrantes» que, según dispone, «se crioconservarán en los bancos autorizados, por un máximo de cinco años» ${ }^{55}$. El Tribunal considera que es una «inevitable consecuencia de estas técnicas» y la legitima constitucionalmente porque «de la Constitución no se desprende la imposibilidad de obtener un número suficiente de preembriones necesario para asegurar, con los conocimientos biomédicos actuales, el éxito probable de la técnica de reproducción asistida que se esté utilizando, lo que, desde otra perspectiva, supone admitir como un hecho científicamente inevitable la eventual existencia de preembriones sobrantes» (FJ $1 .^{\circ}$ ). Por otra parte, sigue diciendo la sentencia, estos nuevos preembriones, no son «persona humana», «por lo que el hecho de quedar a disposición de los bancos tras el transcurso de determinado plazo de tiempo, difícilmente puede resultar contrario al derecho a la vida (art.15 CE) o a la dignidad humana (art. 10.1 CE)» (id.).

Una vez más llama la atención el escaso esfuerzo argumentativo del Tribunal: Por lo que se refiere a la generación de embriones que no se implantarán, todo el argumento se reduce a la eficacia de la fecundación unida a una apelación a lo «científicamente inevitable». Pero, de un lado, la llamada a la ciencia no resulta convincente cuando en otros países no se permite generar más embriones que los que se van a transferir y, en cualquier caso, no hay en la sentencia la menor ponderación, al menos desde el principio de proporcionalidad, sino una prevalencia total del criterio de eficacia: ¿justifica el éxito de la técnica — que por otra parte se da en porcentajes relativamente reducidos - la generación de un número ilimitado de embriones?

Quizás la explicación está implícita en el segundo de los párrafos trascritos: para el Tribunal la protección de los preembriones parece no afectar ni al derecho a la vida ni a la dignidad. Ya ni siquiera se hace esfuerzo argumental alguno desde el punto de vista del mandato de protección del art. 15 CE que, según la STC 53/1985, se extiende sobre la vida humana en todo su curso, desde la gestación hasta la muerte. Por el contrario, el Tribunal usa por primera vez el concepto persona humana y lo hace para descartar cualquier protección y, en la práctica, equiparar a estos embriones con los gametos. Como antes se ha señalado, en la sentencia sobre el aborto el Tribunal evitó expresamente entrar en la polémica de cuándo se empieza a ser persona; ahora, sin embargo, afirma sin la menor justificación, y sin consideración alguna sobre qué debe considerarse persona a los efectos constitucionales, que el preembrión no lo es. Quizás ello tenga que ver con el deseo de negar cualquier proyección de la dignidad que en el art. 10.1 CE se vincula al concepto de persona; volveré sobre ello enseguida.

55 A. Ollero ha llamado la atención sobre las implicaciones del hecho mismo de llamar sobrantes a determinados preembriones, algo que «desborda con mucho la constatación científica, para implicar una nueva valoración ética de notable calado» (Bioderecho. Entre la vida y la muerte, cit., pág. 170). 
Y la consecuencia inevitable de que haya embriones sobrantes es la existencia de bancos para su crioconservacion ${ }^{56}$ : nada considera necesario decir el Tribunal sobre si es compatible con el valor vida y con la dignidad del ser humano generar embriones cuyo destino no va a ser la vida ${ }^{57}$, ni sobre el hecho de que el plazo para la conservación sea de cinco años sin que la ley disponga qué debe hacerse trascurrido ese tiempo, ni sobre el alcance constitucional de esa omisión. La consecuencia, esa sí inevitable, es que en los bancos se acumularon decenas de miles de preembriones y que hasta 2003 - es decir, quince años después de la entrada en vigor de la ley - nadie asumió la decisión de qué hacer trascurrido el plazo de cinco años.

iv) La ausencia de tutela penal

Otro aspecto de las leyes objeto de impugnación fue la ausencia de cualquier tipo de tutela penal de los embriones. La alegación por parte de los recurrentes no parecía a priori temeraria si se tiene en cuenta el énfasis con que la STC 53/1985 insistía en que la protección de la vida que se desprende del art. 15 CE alcanza también a la vida en formación y en que dicha tutela debía incluir la vía penal, si bien declaró también que esta, «en determinados supuestos puede y aún debe estar sujeta a limitaciones» (FJ 7). Con apoyo en esta afirmación final, entiende el Tribunal que una cosa es que la ausencia de toda protección penal pueda justificar un recurso de inconstitucionalidad y otra que cada una de las posibles infracciones deba tener como consecuencia la imposición de una pena (SSTC 212/1996 FJ 10 y 116/1999, FJ 16). El caso es que — más allá de las conductas reconducibles a un delito de aborto- ninguna de las dos leyes establecía sanción penal alguna. Quizás justifica la decisión del Tribunal el hecho, puesto de relieve en ambas sentencias, de que el nuevo Código Penal de 1995 había tipificado posteriormente como delito algunas de esas infracciones ${ }^{58}$. Pero si bien es cierto que con esto podía entenderse que había desaparecido en esos concretos puntos el objeto del recurso, no lo es menos que la opción del legislador siete años después de la aprobación de las leyes impugnadas venía más bien a confirmar la necesidad de una mayor tutela, también por vía penal.

56 Dirá el Tribunal que la crioconservacion no solo no atenta contra la dignidad humana sino que es el único remedio para mejor utilizar los preembriones ya existentes (FJ 11). Pero, como con toda razón señala V. Bellver, la cuestión no es si resulta menos atentatorio contra la dignidad humana congelar los embriones que destruirlos «sino si tiene trascendencia que aparezcan bancos de embriones congelados con los que, a medio plazo, no se sabe qué hacer» («El estatuto jurídico del embrión», cit., pág. 262).

57 Como ha dicho A. Ollero con palabras fuertes pero gráficas, «con la fecundación "in vitro" surge la novedosa figura del "moriturus": un ser humano fabricado para morir, una vez cumplida la función meramente instrumental a la que estaba destinado" (Bioderecho. Entre la vida y la muerte, cit., pág. 160).

58 En efecto, el Título V del Libro II del nuevo Código tipifica diversos delitos relativos a la manipulación genética, en especial la alteración del genotipo (art. 159), la fecundación de óvulos para fines distintos de la procreación (art. 160.2), la clonación (art. 160.3), así como la fecundación in vitro de una mujer sin su consentimiento (art. 161). 
v) Un concepto débil de dignidad

Quizás uno de los aspectos más llamativos de las dos sentencias que estamos comentando es lo escasamente presente que está la dignidad humana en los razonamientos del Tribunal. A diferencia de lo que ocurre, por ejemplo, en la Constitución alemana, el art. 10 CE no configura la dignidad como un derecho fundamental, pero la considera junto con «los derechos inviolables que le son inherentes» como «el fundamento del orden político y la paz social».

Por lo que se refiere a la STC 212/1996, y en relación con los embriones y fetos humanos abortados, el Tribunal admite que la dignidad de la persona «pueda tener una cierta proyección en determinados aspectos de la regulación de los mismos» (FJ 5) y señala que la patrimonialización que había sido denunciada por los recurrentes (al igual que ocurriría con órganos humanos o incluso el cadáver de una persona), «sería desde luego incompatible con su dignidad» (FJ 8). No obstante, no saca consecuencia alguna de esas afirmaciones y llega a sostener que «el embrión abortado no es sino una estructura celular sin posibilidad de ulterior desarrollo» (FJ 6).

Mayor trascendencia tienen algunas de las afirmaciones que se contienen en la STC 116/1999, también por la mayor incidencia en el valor dignidad humana de algunas de las previsiones de la Ley de reproducción asistida ${ }^{59}$. En algunos pasajes, el Tribunal parece cuestionar que se trate de un valor predicable de los embriones, al menos antes de su implantación en el útero. Así, al referirse a los preembriones no viables, afirma que con esa expresión se hace referencia «a su incapacidad para desarrollarse hasta dar lugar a un ser humano, a una 'persona' en el fundamental sentido del art. 10.1 CE» (FJ 9). Y de forma más clara, en relación con su crioconservacion, afirma que «ni los preembriones no implantados ni, con mayor razón, los simples gametos son, a estos efectos, 'persona humana', por lo que del hecho de quedar a disposición de los Bancos tras el transcurso de determinado plazo de tiempo, difícilmente puede resultar contrario al derecho a la vida (art. 15 C.E.) o a la dignidad humana (art. 10.1 C.E.)» (FJ 11$)^{60}$.

59 Esa importante incidencia es la que lleva a formular un voto particular disidente a los Magistrados Jiménez de Parga y Garrido Falla, si bien sus razonamientos no se centran en aspectos sustantivos sino en la consideración de que la ley hubiera debido tener carácter orgánico.

${ }^{60}$ Sin embargo, previamente había afirmado que la crioconservación «no sólo no resulta atentatoria a la dignidad humana, sino que, por el contrario y atendiendo al estado actual de la técnica, se nos presenta más bien como el único remedio para mejor utilizar los preembriones ya existentes, y evitar así fecundaciones innecesarias» (FJ 11). Esta afirmación, y la antes transcrita de que la patrimonialización de los preembriones sería contraria a la dignidad, llevan a F.J. Díaz Revorio a considerar que de la jurisprudencia del Tribunal puede entenderse que a los embriones les alcanza la protección constitucional de la dignidad humana, algo que él entiende se desprende de la Constitución y con lo que estamos de acuerdo («Bioética y valores constitucionales en el comienzo de la vida humana», cit., pág. 809); pero las otras citas de la sentencia que hemos transcrito en el texto parece que dejan lugar a pocas dudas. 
Esta exclusión de la dignidad en las primeras etapas de la vida humana en formación y el escaso peso que el Tribunal le da, en general, a lo largo de sus sentencias resulta tanto más llamativa cuanto se trata de un valor especialmente relevante en el ámbito del Bioderecho ${ }^{61}$. Y es que si la dignidad es un valor estrechamente unido a la condición de ser humano difícilmente se le puede negar a este en sus etapas iniciales. Como ha expuesto con especial claridad E.W. Böckenförde, la dignidad no puede vincularse a determinadas propiedades, signos o capacidades sino que le corresponde a todo ser humano con independencia del estado de desarrollo en que se encuentre y debe regir desde el primer momento de su vida y no tras un plazo que haya debido superar sin estar protegido frente al capricho y la discrecionalidad ${ }^{62}$.

\section{LA EVOLUCIÓN LEGISLATIVA}

Como ya se ha señalado, la aplicación de la ley dio lugar al almacenamiento de miles de embriones crioconservados. Este hecho, y los avances de la técnica que han permitido su utilización para fines de investigación, especialmente para la obtención de células troncales, motivó la aprobación de una nueva ley (Ley 45/2003, de 21 de noviembre) que modificaba algunos aspectos relevantes de la normativa de 1988 tal y como, por otra parte, había aconsejado la Comisión Nacional de Reproducción Asistida.

Consideró el legislador que el elevado número de preembriones congelados sugería que no era necesario obtener tantos y, por ello, estableció que se fecundaría un máximo de tres ovocitos que puedan ser transferidos a la mujer en el mismo ciclo (art. 4.3). Por otra parte, para reducir el número de partos múltiples, se estableció un límite máximo de tres preembriones que pueden ser transferidos a la mujer en cada ciclo (art. 4.2).

Asimismo se modificó el art. 11 de la Ley estableciendo que, en los casos excepcionales en que a pesar de las nuevas limitaciones se generen embriones sobrantes, se conservarán por un plazo equivalente a la vida fértil de la mujer, debiendo los proge-

${ }^{61}$ La extensión al embrión de la dignidad humana a la que se refiere el art. 1 de la Carta de Derechos Fundamentales de la Unión Europea es una de las claves de la importante sentencia del Tribunal de Justicia de la Unión Europea, de 18 de octubre de 2011 (Gran Sala), Oliver Brüstle c Greenpeace Ev., en la que declaró que a los efectos de la Directiva 94/44/CE sobre protección jurídica de las invenciones biotecnológicas, «debe considerarse un «embrión humano» todo óvulo humano a partir del estadio de la fecundación, todo óvulo humano no fecundado en el que se haya implantado el núcleo de una célula humana madura y todo óvulo humano no fecundado estimulado para dividirse y desarrollarse mediante partenogénesis», así como «la exclusión de la patentabilidad en relación con la utilización de embriones humanos con fines industriales o comerciales» (vid. P. Nuevo López, «¿Primer paso hacia un estatuto jurídico comunitario del embrión humano?», Revista de Derecho Comunitario Europeo, núm. 42, 2012, págs. 593-605).

${ }^{62}$ Cfr. E.W. Böckenförde, «Menschenwürde als normatives Prinzip. Die Grundrechte in der bioethischen Debatte», Juristen Zeitung, 2003, págs. 809-815. 
nitores firmar un compromiso en el que otorgarán el consentimiento para que, si no fueran transferidos, sean donados con fines reproductivos como única alternativa (apartado 3).

Por último, y para dar salida a los miles de preembriones congelados con anterioridad a la Ley, la Disposición adicional primera establecía que los progenitores debían optar entre el mantenimiento de la crioconservación hasta que sean transferidos, la donación a otras parejas o el consentimiento para que sean utilizadas con fines de investigación ${ }^{63}$.

A pesar de las moderadas limitaciones de la ley, en línea con otras legislaciones europeas, y de que además venía a permitir el uso de embriones para la investigación, recibió numerosas críticas por parte de los partidarios de una fecundación in vitro sin limitaciones. Y de hecho las reformas duraron poco porque en 2006 se aprobó la Ley 14/2006, de 26 de mayo, sobre técnicas de reproducción humana asistida, que vino a derogar la normativa anterior y constituye la legislación hoy vigente ${ }^{64}$. La nueva regulación eliminó el límite de un máximo de tres ovocitos porque «dificulta la práctica ordinaria de las técnicas de reproducción asistida, al impedir poner los medios para lograr el mayor éxito con el menor riesgo posible para la salud de la madre» (Exposición de Motivos) y suprimió, asimismo, el diferente trato que se podía dar a los preembriones congelados según fueran previos a la entrada en vigor de la Ley de 2003 o posteriores, autorizando que todos puedan ser destinados a la investigación si concurre el consentimiento de los progenitores (art. 11) y se dan otra serie de requisitos: que no se haya desarrollado in vitro más allá de catorce días y que la investigación sea realizada en centros autorizados y con base en un proyecto también debidamente autorizado por las autoridades sanitarias (art. 15). Como novedad, la ley define por primera vez el preembrión, entendiendo por tal «el embrión in vitro constituido por el grupo de células resultantes de la división progresiva del ovocito desde que es fecundado hasta 14 días más tarde» ${ }^{65}$.

Con la nueva legislación ${ }^{66}$, España es uno de los países con menos restricciones en la reproducción asistida: cabe el tratamiento a la mujer soltera, la donación de semen y de óvulos, el anonimato del donante, el diagnóstico preimplantacional, la fecunda-

${ }^{63}$ No deja de llamar la atención el cambio de lenguaje de la ley para referirse a los preembriones descongelados: «material biológico» se les denomina en la exposición de motivos y «estructuras biológicas» en la Disposición final primera.

${ }^{64}$ Un extenso análisis de esta ley se contiene en J.A. Cobacho Gómez (Dir.) y J.J. Iniesta Delgado (coord..), Comentarios a la Ley 14/2006, de 26 de mayo, de Reproducción Humana Asistida, Thomson Aranzadi, Cizur Menor 2007.

65 Es significativo que se defina al preembrión como un «embrión», lo que parece confirmar la cierta artificiosidad en la distinción entre embriones y preembriones que, sin embargo y como antes se ha visto, tiene importantes consecuencias prácticas.

${ }^{66} \mathrm{Ni}$ esta ley ni la anterior fueron objeto de impugnación ante el Tribunal Constitucional. Tampoco lo fue la Ley 14/2007, de 3 de julio, de Investigación biomédica, que derogó la Ley 42/1988, de donación y utilización de embriones y fetos humanos o de sus células, tejidos u órganos, y cuyo título IV regula la obtención y uso de células y tejidos de origen embrionario humano. 
ción post mortem y la selección de sexo en caso de enfermedades hereditarias ligadas a este. No son pocos los que celebran una legislación tan avanzada que, como contrapartida, lo es también en la desprotección de la vida embrionaria.

\section{UN MODELO DE (DES)PROTECCIÓN GRADUALISTA DE LA VIDA EN FORMACIÓN}

Como consecuencia de la jurisprudencia constitucional estamos hoy ante una protección gradualista de la vida humana en formación, algo que ha sido ya descrito —y defendido - por algunos autores. Quizás la formulación más clara de esta gradación es la que realiza C.M. Romeo Casabona ${ }^{67}$ y que, yendo de mayor a menor protección, incluye:

1. El feto que es capaz de continuar su proceso vital sin la concurrencia de la madre (viabilidad extrauterina)

2. El embrión anidado o implantado en el endometrio materno

3. El embrión viable, que está en condiciones de continuar el proceso de desarrollo biológico de forma natural

4. El embrión in vitro antes de ser transferido a una mujer

5. El embrión no viable por presentar anomalías incompatibles con la vida: a su vez, la protección iría de más a menos según se trate de a) el embrión in utero, b) el embrión ex utero y c) el embrión in vitro

De acuerdo con la doctrina del Tribunal Constitucional, ninguno de ellos tendría derecho a la vida, si bien gozarían de la protección que se desprende del art. 15 CE. Ahora bien, este protección no será nunca la propia del nacido y su alcance concreto tampoco será claro pues, en la práctica, dependerá de los avances de la técnica y de la percepción de la sociedad ${ }^{68}$ : el embrión en útero solo podía ceder inicialmente en

${ }^{67}$ «El derecho a la vida: aspectos constitucionales de las nuevas biotecnologías», cit., págs. 40 y sigs. A la idea de una explicación gradualista de la protección de la vida según la doctrina constitucional acude también F.J. Díaz Revorio, («Bioética y valores constitucionales en el comienzo de la vida humana», cit., págs. 805 y sigs.), si bien considera que la gradualidad sería admisible en relación con el derecho a la vida y no respecto de la dignidad (pág. 810) y reclama una definición más clara del preembrión que no sería una persona pero sí perteneciente a la especie humana y al que, por tanto, alcanza la protección de la dignidad (pág. 812). Partidario asimismo de una protección gradual, que incluiría también la dignidad humana, se muestra E. Peñaranda Ramos, «Bioética y Derecho Penal en el comienzo de la vida: algunas implicaciones jurídico-penales de las nuevas biotecnologías», Anuario de la Facultad de Derecho de la Universidad Autónoma de Madrid, número extra, 2006, págs. 99 y sigs.

${ }_{68}$ Así ocurrió, como hemos visto, con los embriones llamados «viables»: inicialmente solo se podía intervenir en ellos con fines terapéuticos (STC 212/1996, FJ 5). Posteriormente, cuando los avances técnicos han permitido aprovechar las células embrionarias para la investigación, se consideró también constitucional la destrucción de embriones congelados, que serían viables si fueran implantados («viables», por tanto, biológicamente en el sentido antes visto). 
determinados supuestos — sistemas de indicaciones - y hoy cede ante la voluntad libre de la mujer durante las catorce primeras semanas. En cuanto al embrión generado in vitro, viene protegido por el art. $15 \mathrm{CE}$ una vez que sea viable y sea de hecho transferido al útero de una mujer; si no es viable, aunque sea un ser humano vivo, no parece tener protección alguna derivada del art. $15 \mathrm{CE}$ ni de la dignidad de la persona (art. $10 \mathrm{CE}$ ); y mientras sea viable pero no haya sido transferido, quedará congelado y congelada queda también la protección constitucional hasta que sus progenitores decidan si se implanta o se dona a otra pareja (en cuyo caso seguirá teniendo la protección constitucional), o si se utiliza para la investigación, en cuyo caso la protección cederá por completo.

Esta división no parece muy acorde con la consideración de la vida como un continuum tal y como afirmó la STC 53/1985 y parece confirmar la ciencia de forma cada vez más clara ${ }^{69}$. Es verdad que en esa sentencia se afirma también que ella «es un continuo sometido por efectos del tiempo a cambios cualitativos de naturaleza somática y psíquica que tienen un reflejo en el status jurídico público y privado del sujeto vital» (FJ 6). Pero desde el punto de vista constitucional, la pregunta es si entre esos cambios hay algunos tan relevantes como para permitir la total eliminación de la vida sin consecuencias jurídicas: desde luego no es así después del nacimiento, a pesar de producirse cambios relevantes (autoconciencia, mayoría de edad) o de que el nacido tenga —o desarrolle posteriormente- muy graves discapacidades. Y entendemos que tampoco debería serlo durante la gestación ${ }^{70}$.

${ }^{69}$ Señala, sin embargo, E. Peñaranda Ramos que «la supuesta continuidad del proceso vital depende en realidad de la intervención de terceros, en primer lugar del médico que realiza la implantación; pero especialmente de la mujer, que aún ha de decidirse a ella en ejercicio de un derecho que pertenece a su esfera más íntima» («Bioética y Derecho Penal en el comienzo de la vida: algunas implicaciones jurídico-penales de las nuevas biotecnologías», cit., págs. 105-106). El razonamiento adopta, sin embargo, un punto de partida que el autor da por supuesto: la licitud de engendrar embriones in vitro no destinados a ser implantados, algo que, por las razones ya reiteradas, no consideramos respetuoso ni con la dignidad del ser humano (art. 10 CE) ni con el derecho a la vida (con el que tampoco parece compatible un derecho absoluto de la mujer a decidir).

${ }^{70}$ Puede verse un buen e interesante resumen de algunas de las razones que han llevado a no pocos penalistas alemanes a considerar inaceptable el establecimiento de cualquier diferencia valorativa atendiendo al estadio en que la vida se encuentre en E. Peñaranda Ramos, «Bioética y Derecho Penal en el comienzo de la vida: algunas implicaciones jurídico-penales de las nuevas biotecnologías», cit., págs. 87 y sigs., si bien, como hemos dicho, no son compartidas por este autor, partidario de un modelo de protección gradual de la vida humana (págs. 99 y sigs.). 
Title:

The constitutional status of the unborn: evolution and current situation in Spain

\section{Summary:}

1. The Introduction Of Abortion In Spain And The STC 53/1985: a) From Criminalization To Decriminalization In Certain Circumstances; b) STC 53/1985: i) Right To Life And Prenatal Life; ii) The Life Of The Unborn As A Constitutional Interest; iii) The Constitutionality Of The Indication System; iv) The Conditions For The Constitutionality Of Decriminalization; c) The New Regulation. 2. From The «Indication System» To The «System Of Deadlines»: Organic Law 2/2010 Of 3 March On Sexual And Reproductive Health And Voluntary Termination Of Pregnancy: a) The Evolution Of Abortion In Spain Under The 1985 Act; b) The Arguments For The Reform And The Context Of The New Regulation; c) The New Regulation. 3. An Open Debate: a) The Conditions For The Constitutionality Of Decriminalization; b) The Failed Reform Of The Act. 4. The Weak Protection Of The Embryo In The Legislation On In Vitro Fertilization And The Use Of Embryonic Organs And Tissues, And The SSTC 212/1996 And 116/1999: a) Act 35/1988 On Assisted Reproduction Techniques, And Act 42/1988 On Donation And Use Of Human Embryos And Fetuses And Their Cells, Tissues And Organs; b) Negation Of The Right To Life Of The Embryo And Consequences For Its Consideration As A Constitutionally Protected Legal Interest: i) The Embryo Does Not Hold The Right To Life; ii) Two New Categories: Pre-Embryos And Non-Viable Embryos And Their Legal Relevance; iii) Surplus Embryos; iv) The Absence Of Any Criminal Protection; v) A Weak Concept Of Dignity. 5. Legislative Evolution; 6. A Model For The Gradual (Dis)Protection Of Unborn Human Life:

\section{Resumen:}

El presente trabajo es un análisis de cómo ha evolucionado la protección del no nacido en España desde la aprobación de la Constitución de 1978. Se centra, en particular en el estudio de la legislación y de la jurisprudencia constitucional sobre dos temas especialmente relevantes y controvertidos: la regulación del aborto, de un lado, y de la fecundación in vitro y uso de embriones, sus tejidos y órganos, de otro. Tanto el legislador como la doctrina del Tribunal Constitucional se han inclinado por una protección gradualista de la vida humana en formación que deja abiertos muchos interrogantes desde la perspectiva del derecho a la vida (art. 15 CE) y la dignidad humana (art. 10.1 CE) 


\begin{abstract}
:
This paper analyzes the evolution of the protection of the unborn human life in Spain since the enactment of the 1978 Constitution. It focuses, in particular, on the study of the laws and the constitutional jurisprudence on two relevant matters: the regulation of abortion; and the in vitro fertilization, the use of embryos their tissues and organs. The legislator and the decisions of the Constitutional Court have opted for gradualist protection of the embryo that leaves many questions open from the perspective of the right to life (Article 15 SC) and human dignity (Article 10.1 SC)
\end{abstract}

\title{
Palabras claves:
}

Derecho a la vida, vida humana en formación, aborto, fecundación in vitro, embrión

\section{Key words:}

The right to life, unborn human life, abortion, in vitro fertilization, embryo 